\title{
MOLECULAR PHYLOGENY OF GUANARITO VIRUS, AN EMERGING ARENAVIRUS AFFECTING HUMANS
}

\author{
JEAN-PAUL GONZALEZ, ANTHONY SANCHEZ, AND REBECA RICO-HESSE \\ Institut Francais de Recherche Scientifique pour le Developpement en Cooperation ORSTOM, Paris, \\ France; Special Pathogens Branch, Division of Viral and Rickettsial Diseases, National Center \\ for Infectious Diseases, Centers for Disease Control and Prevention, Atlanta, Georgia; \\ Department of Epidemiology and Public Health, Yale University School of Medicine, New Haven, \\ Connecticut
}

\begin{abstract}
The nucleotide sequence of a portion of the nucleocapsid $(\mathrm{N})$ gene of the Guanarito virus prototype strain (INH-95551) has been determined. It was obtained by direct RNA and polymerase chain reaction (PCR) fragment sequencing of the $3^{\prime}$ end of the small (S) RNA fragment. A comparison of this 782-nucleotide segment was done with the known homologous gene sequences of five other arenaviruses: Junin, Machupo, Tacaribe, Pichinde, and lymphocytic choriomeningitis (LCM). Phylogenetic analysis of the $N$ gene open reading frame showed that Guanarito virus is genetically distinct from other members of the Arenavirus family, with $32 \%$ nucleotide sequence divergence from Junin, $30 \%$ from Machupo, 32\% from Tacaribe, $41 \%$ from Pichinde, and $45 \%$ from LCM. Comparison of amino acids encoded by this sequence region indicated a probable antigenic domain (amino acids 55-63) shared among all arenaviruses studied to date. Along with its host restriction and focal distribution, our data support the hypothesis that this virus has been evolving independently in its endemic focus, for some time.
\end{abstract}

There are now five arenaviruses recognized as human pathogens in the Americas: Junin (JUN), Machupo (MAC), Flexal (FLEX), Guanarito (GUA) and Sabia (SAB); the last two have emerged only recently. ${ }^{1,2}$ Venezuelan hemorrhagic fever (VHF), caused by GUA virus, was first detected in 1989; 105 presumed cases and 26 deaths were reported by 1992 and many strains have been isolated from both humans and rodents. ${ }^{13}$ However, despite noticeable virus activity in the rodent population, ${ }^{3}$ no human cases were reported from 1993 to date (Salas RA, unpublished data). Because VHF arose suddenly, with a high mortality rate and clinical features similar to Argentine hemorrhagic fever and Bolivian hemorrhagic fever, which are caused by JUN and MAC viruses, respectively, a major concern was to determine the origin of GUA virus and its degree of relatedness to other arenaviruses.

Arenaviruses have a single-stranded RNA genome of two segments, $L$ (large) and $S$ (small), with average lengths of 7,100 and 3,400 nucleotides, respectively. ${ }^{+-6}$ The L RNA segment encodes at least two proteins, a viral polymerase and a zinc-binding protein. ${ }^{7}$ The LCM (Armstrong strain) virus $S$ RNA encodes, in an ambisense manner, a 558-amino acid nucleocapsid (N) protein from the $3^{\prime}$ end and a 498amino acid glycoprotein precursor (GPC) from the $5^{\prime}$ end, which undergoes post-translational cleavage to generate the mature glycoproteins GPI and GP2.5 The messenger sense of the GPC requires a full replication cycle for expression, while the messenger sense of the $\mathrm{N}$ gene can be expressed directly by limited viral polymerase activity on the viral RNA template..$^{5,8}$

The large amount of antigenic cross-reactivity observed between different arenaviruses has made it difficult to identify and organize strains within the family and to understand how these viruses are related to each other. Two distinct serogroups can be clearly identified by immunofluorescent antibody and complement fixation tests: the Old World or LCM-Lassa serogroup and the New World or Tacaribe (TAC) serogroup. ${ }^{9}$ However, serologic approaches for distinguishing species within these two groups are different, de- pending on the origin of the strains. The standard plaquereduction neutralization test can be used to distinguish among arenaviruses from the New World but not among those from the Old World. It is necessary to incorporate either complement or anti-gamma globulin in the neutralization test to increase its sensitivity and to distinguish strains from the Old World. This does not permit a direct comparison of neutralization titers for strains from the two groups. ${ }^{10}$

Nucleotide and amino acid sequence analyses have given some insight into the genetic relationships of several members of the Arenavirus family from various geographic origins. Phylogenetic trees have been generated using the complete N, GP1, or GP2 genes sequences, to determine relationships within the family, and to select potential vaccine strains." To develop a more rapid and precise technique for virus identification and phylogeny, we compared nucleotide sequences from a small portion of the arenavirus $\mathrm{N}$ gene. This approach, limited sequence analysis, has been used previously to generate evolutionary trees of many different viruses. This is the first report of its use on arenaviruses.

\section{METHODS}

Virus growth and purification. The prototype strain (INH-95551) of GUA virus, isolated from a human case of VHF in $1989^{\prime}$ was used at a low-passage level (human rhabdomyosarcoma cells, one passage; suckling mouse, two passages; Vero E6 cells, one passage). Growth and purification were carried out as previously described for other arenaviruses. ${ }^{12}$ Briefly, expanded roller bottles (Corning, Corning, NY) of a confluent Vero E6 monolayer were inoculated at a low multiplicity of infection $(<1$ plaque-forming unit/cell). After $72 \mathrm{hr}$ postinoculation (pi), the supernatant was harvested and the cells were refed with minimum essential medium containing $2 \%$ fetal bovine serum. Two additional harvests were done at 96 and $120 \mathrm{hr}$ pi. The virus was concentrated by precipitation with $7 \%$ polyethylene glycol and $2.3 \% \mathrm{NaCl}$. Precipitated proteins and virus particles were pelleted and resuspended in sterile TS buffer $(50 \mathrm{mM}$ Tris$\mathrm{HCl}, 100 \mathrm{mM} \mathrm{NaCl}, \mathrm{pH}$ 7.5). A second centrifugation was 
done to pellet cellular debris. The viral suspension was concentrated by two successive ultacentrifugations: first, the virus was pelleted through a $30 \%$ sucrose cushion (SW55Ti rotor; Beckman, Palo Alto, CA) at $40,000 \mathrm{rpm}$ for $3 \mathrm{hr}$, then layered on a glycerol-potassium tartrate gradient. ${ }^{13}$ The visible band of purified viral particles was diluted in TSE buffer (10 mM Tris- $\mathrm{HCl}, 150 \mathrm{mM} \mathrm{NaCl}, 2 \mathrm{mM}$ EDTA, pH 7.8) and pelleted by centrifugation at $40,000 \mathrm{rpm}$ for $3 \mathrm{hr}$. The virus pellet was resuspended in $400 \mu \mathrm{I}$ of TSE buffer and was used for immediate RNA extraction.

Extraction of RNA. The RNA was extracted either with phenol:chloroform as previously described ${ }^{14}$ or with Trizol (GIBCO-BRL, Gaithersburg, MD). Trizol RNA extraction was performed according to the manufacturer's protocol and used for small volumes $(<150 \mu \mathrm{I})$ of infected cells at three days pi. Ethanol-precipitated RNA was recovered by centrifugation and air-dried. The RNA pellet was resuspended in $10 \mu \mathrm{l}$ of TE buffer $(10 \mathrm{mM}$ Tris- $\mathrm{HCl}, \mathrm{pH} 7.8,1 \mathrm{mM}$ EDTA) for direct sequencing or diethyl pyrocarbonate (DEPC)-treated water for the reverse transcriptase-polymerase chain reaction (RT-PCR).

Sequencing of RNA. Nucleotide sequences from the $3^{\prime}$ end of the S RNA segment of GUA virus were obtained using the dideoxynucleotide chain termination method of Sanger and others ${ }^{15}$ with a few modifications. ${ }^{14}$ Three synthetic primers were designed using the $5^{\prime}$ end of the obtained sequences, beginning with an arenavirus consensus primer described by others (ARE3'END, 5'-CGCACAGTGGATCCTAGGC-3'): ${ }^{\prime 6}$ GUA/2740, 5'-GTGCAGGCACTAACATC-3'; GUA/2916, 5'-CTTGAVGCAGYCAATTGG-3'; and GUA/3127,5'-CCAAACGAGGAGACACTG-3' $(\mathrm{V}=$ $\mathrm{G}, \mathrm{A}$, or $\mathrm{C}$ and $\mathrm{Y}=\mathrm{C}$ or $\mathrm{T}$ ). Primer numbers refer to map sites on the JUN virus genome. ${ }^{17}$ Resuspended viral RNA was mixed with a five-fold molar excess of DNA primer and heated to $90^{\circ} \mathrm{C}$ for $90 \mathrm{sec}$, then equilibrated to room temperature to allow for hybridization. Sequencing reactions and gel autoradiography were carried out as previously described. ${ }^{14}$

Reverse transcriptase-polymerase chain reaction. The RT-PCR was used to confirm sequences obtained by direct $S$ RNA sequencing. The RT reaction was used to obtain cDNA from viral RNA, for amplification by the PCR. An arenavirus S RNA-complementary oligonucleotide, ARE3'END, 5'-CGCACAGTGGATCCTAGGC-3', was used to prime the first strand of cDNA synthesis. The reaction tube contained $1 \mu \mathrm{l}$ of viral RNA, $2 \mu \mathrm{l}$ of $5 \times \mathrm{H}$-RT buffer (GIBCO-BRL), $1 \mu \mathrm{I}$ (40 U) of RNAsin (Promega, Madison, WI), $1 \mu \mathrm{l}$ of $100 \mathrm{mM}$ DTT (GIBCO-BRL), $1 \mu \mathrm{l}$ (200 U) of Superscript II reverse transcriptase (GIBCO-BRL), and $4 \mu$ of $10 \mathrm{mM}$ deoxynucleotides (Perkin-Elmer Cetus, Norwalk, $\mathrm{CT}$ ) and was incubated at $37^{\circ} \mathrm{C}$ for $1 \mathrm{hr}$. A viral genome sense oligonucleotide, GUA/2596V,5'-AGTTATNATCGAGATATGTGTTNAGTGC-3' $(\mathrm{N}=\mathrm{A}, \mathrm{G}, \mathrm{C}$, or $\mathrm{T})$, which binds to the middle of the $\mathrm{N}$ gene region (JUN map site 2596-2623), ${ }^{17}$ was used to prime the second strand synthesis. Samples for the PCR were prepared as follows: $10 \mu \mathrm{l}$ of cDNA template (from the RT reaction), $500 \mathrm{pmol}$ of each primer $(2 \times 3 \mu 1), 5 \mu l$ of $10 \times$ buffer (GIBCO-BRL), and DEPC-treated water to bring the volume to $49 \mu \mathrm{l}$. This solution was heated at $90^{\circ} \mathrm{C}$ for $90 \mathrm{sec}$ and cooled on ice before adding $1 \mu \mathrm{l}(5 \mathrm{U})$ of Taq polymerase (Ampli Taq DNA poly- merase; Perkin-Elmer Cetus); $100 \mu \mathrm{l}$ of mineral oil was added to prevent evaporation and the tube was transferred to a thermocycler (Perkin-Elmer). The cycling program consisted of one 2 -min elongation step at $72^{\circ} \mathrm{C}$, followed by 40 cycles of denaturation at $92^{\circ} \mathrm{C}$ for $1 \mathrm{~min}$, annealing at $40^{\circ} \mathrm{C}$ for 1 min, and elongation at $72^{\circ} \mathrm{C}$ for $1 \mathrm{~min}$. The product was stored at $4^{\circ} \mathrm{C}$.

Amplified DNA products were separated by electrophoresis in a 3\% NuSieve (FMC Bioproducts, Rockland, ME), $1 \%$ agarose gel using TAE buffer $(40 \mathrm{mM}$ Tris-acetate, 1 mM EDTA), and the expected PCR product band was sliced out and the DNA was extracted from the agarose. Agarose digestion was performed using $\beta$-agarase (New England Biolabs, Beverly, MA); the gel slice was melted in twice its volume of $\beta$-agarase buffer at $65^{\circ} \mathrm{C}$ for $10 \mathrm{~min}$. It was immediately incubated for $1 \mathrm{hr}$ at $37^{\circ} \mathrm{C}$ with $2 \mathrm{U}$ of $\beta$-Agarase per $100 \mu \mathrm{l}$ of agarose. Undigested agarose was removed by cooling on ice and centrifugation $(15,000 \times g$ for $10 \mathrm{~min}$.). The double-stranded cDNA was then ethanol-precipitated in the presence of $4 \mathrm{M} \mathrm{LiCl}$.

To determine the sequence of the PCR fragments, the fmol DNA Sequencing System (Promega) was used according to the manufacturer's protocol. The four previously mentioned primers (GUA/2740, GUA/2916, GUA/3127, and ARE3'END) were labeled with gamma ${ }^{32} \mathrm{P}$-dATP and used at a concentration of $10 \mathrm{nmol}$ per reaction. Cycle sequencing was done by 30 cycles of denaturation at $95^{\circ} \mathrm{C}$ for $30 \mathrm{sec}$, annealing at $40^{\circ} \mathrm{C}$ for $45 \mathrm{sec}$, and elongation at $70^{\circ} \mathrm{C}$ for 30 sec. The product was stored at $-70^{\circ} \mathrm{C}$ and heated at $90^{\circ} \mathrm{C}$ for $90 \mathrm{sec}$ before loading on $6 \%$ and $8 \%$ polyacrylamide gels. The gels were processed for autoradiography as described above. The sequences from the extreme $3^{\prime}$ end of the S RNA were obtained by dideoxynucleotide sequencing using the same cycle-sequencing protocol ( $\mathrm{mol}$; Promega) and a specifically designed primer, GUA/3213V,5'-TTGGCATCACTAAGAACACU-3'.

Computer sequence analysis. Sequence storage and analysis were done using the PCGene software package 6.7 (IntelliGenetics, Mountain View, CA) Amino acid sequence alignment was done with the CLUSTAL program (version 1.2) contained in the PCGene software package. ${ }^{18}$ Phylogenetic analysis was done by a parsimony method search for minimum length trees using the phylogenetic analysis using parsimony (PAUP) software, version 3.1.19 The bootstrap analysis $^{20}$ was used to place confidence limits on the generated phylogenetic trees. This involves random sampling (in this case, 1,000 replications) of the sequence data to infer the variability among the generated trees. The phylogenetic tree selected here represents the majority-rule consensus, showing all the inferred monophyletic groups that occurred in a majority (expressed as percentage) of the bootstrap samples. Sequences for comparisons were obtained through GeneBank (contained in PCGene, CD-ROM format). Prediction of antigenic determinants and site detection in the protein sequence were done using the ANTIGEN and PROSITE programs from the PCGene software. ${ }^{21}$

RESULTS

Nucleotide sequences of the GUA $N$ gene and $3^{\prime}$ noncoding region. The nucleotide sequence of 782 nucleotides 


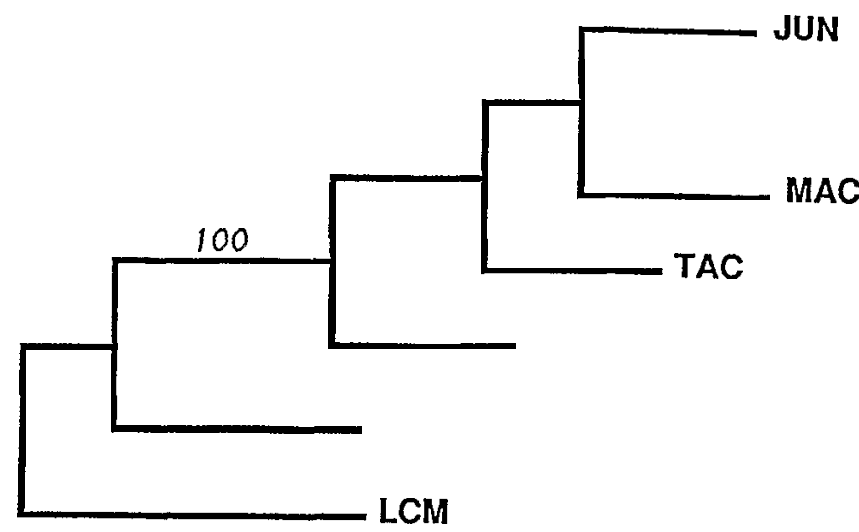

\section{0 nucleotide substitutions}

Figure 1. Phylogenetic tree of arenaviruses, using 739 nucleotides from the $3^{\prime}$ end of the small RNA segment, generated by phylogenetic analysis using parsimony. Lymphocytic choriomeningitis (LCM) virus was used as the outlier of the arenavirus family. The horizontal lines are proportional in length to divergence indicated by the scale bar; above the horizontal lines are bootstrap test values, expressed as a percentage (1,000 replications). A maximum likelihood analysis placed a $P<0.01$ value on the Junin (JUN)-Machupo (MAC) group when substitutions were empirically corrected by assigning an arbitrary value of $3: 1$ for transitions:transversions. TAC $=$ Tacaribe; GUA $=$ Guanarito; $\mathrm{PIC}=$ Pichinde .

from the $3^{\prime}$ end of the S RNA of GUA virus was determined (GenBank accession number L42001). Within the $N$ gene open reading frame, we determined 739 nucleotides, accounting for more than one-third of the $\mathrm{N}$ gene sequence. At the $3^{\prime}$ end, the sequence begins with a nontranslated region of 53 nucleotides until the first UAC codon is found in the viral S RNA. It is known that this codon, in the viral complementary sense mRNA, initiates the $\mathrm{N}$ gene translation. ${ }^{22}$ A 19 -nucleotide sequence at the $3^{\prime}$-terminus that is conserved across all arenavirus S RNAs was present in the GUA virus; because this sequence has been conserved evolutionarily, it is presumed to be the binding site for polymerase. ${ }^{16}$

Comparison of nucleotide sequences from the $\mathrm{N}$ gene. The GUA virus nucleotide sequence was aligned with other arenaviruses using the encoded amino acids alignment. The GUA sequences were compared with those reported for arenaviruses from the Americas, including JUN, ${ }^{17} \mathrm{MAC},{ }^{23}$ $\mathrm{TAC}_{,}{ }^{24}$ and Pichinde (PIC), ${ }^{8}$ and one strain of the widely disseminated LCM virus. ${ }^{25}$ The base ratio found for the partially sequenced S RNA of GUA virus is $24.8 \% \mathrm{~A}, 20.2 \%$ $\mathrm{G}, 21.4 \% \mathrm{C}$, and $33.6 \% \mathrm{U}$, and is comparable with that for JUN. ${ }^{22}$ Only three insertion/deletion events (triplets) were incorporated into two sites of the GUA sequence, to maximize the alignment with other arenaviruses. Phylogenetic trees were generated using only the 739 nucleotides encoding the $N$ gene (excluding the $3^{\prime}$ end noncoding region) (Figure 1). To strengthen the search of the phylogenetic tree, bootstrap analysis was done with 1,000 replicates. Only the portion of the tree containing JUN, MAC, TAC and GUA viruses gave $100 \%$ reproducibility, confirming that these viruses have a common progenitor. It is assumed that once

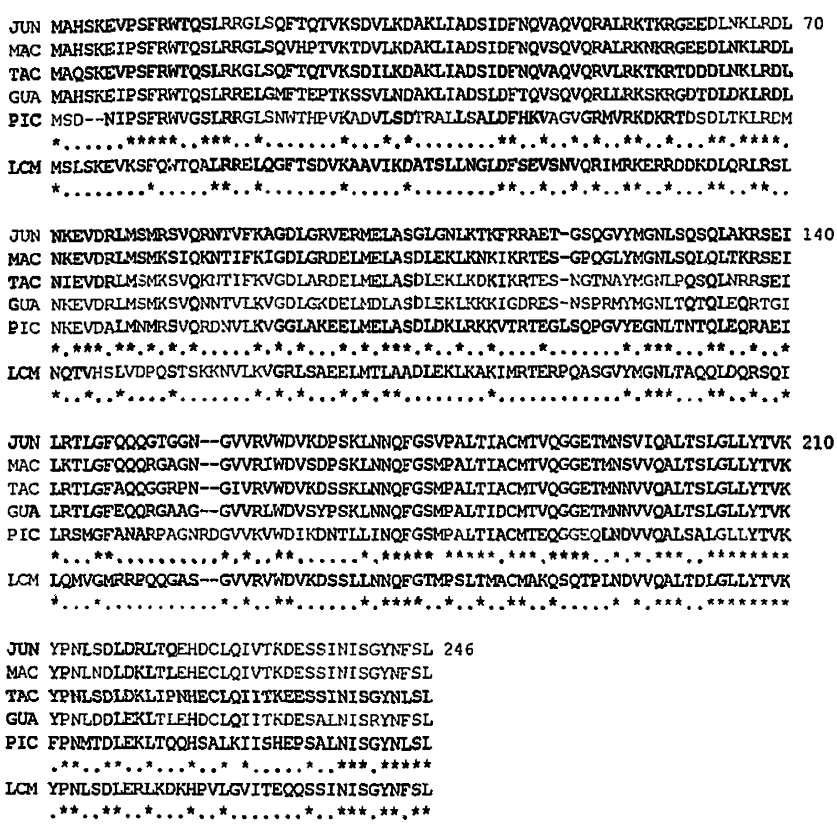

Figure 2. Comparison of the amino acid sequences of a portion of the nuclcocapsid protein of Guanarito (GUA) virus with those of Junin (JUN), Machupo (MAC), Tacaribe (TAG), Pichinde (PIC), and lymphocytic choriomeningitis (LCM) virus strains. The dots indicate an amino acid difference; - indicates a gap in the sequence; $*$ indicates amino acids conserved across the New World arenavirus strains; below LCM indicates those amino acids conserved among New World and LCMI strains.

transition:transversion rates are known for these four viruses, the bootstrap values will improve for the branches within this monophyletic group.

Predicted peptide product and antigenic site. By analogy with other arenavirus S RNA sequences and the known ambisense strategy of encoding the $N$ protein, we identified the start codon for the $N$ gene open reading frame of GUA virus. It is the first UAC triplet in the viral sense that begins at position 54 that encodes (in the ambisense) an AUG initiation codon in the viral mRNA. The encoded $\mathrm{N}$ gene sequence is 246 residues long (Figure 2). A triple basic KKK sequence centered at amino acid position 110 and three groups of two basic $\mathrm{K}$ and/or $\mathrm{R}$ residues are in accord with the previously found relative high frequency of positively charged amino acid residues that are presumably involved in viral infection. ${ }^{22}$

A profile of hydrophilicity revealed three highest points and one of them appeared repeatedly in other arenaviruses (Figure 3). The identified site extends from amino acid residues 55 to 63 . A conserved pair of $\mathrm{K}-\mathrm{R}$ residues in position 58-59, with other hydrophilic residues surrounding it, is consistently found among the arenaviruses, including some strains from the Old World (Lassa from Nigeria and Mopeia from Mozambique). ${ }^{26}$ This suggests that this region may play an important role in antigenicity because its chemical structure (hydrophilicity profile) indicates that it is exposed under physiologic conditions. ${ }^{21}$ Moreover, a potential site for cell attachment (Arg-Gly-Asp [RGD] $)^{27}$ is found within this region in positions 59 to 61 in GUA virus.

Comparison of amino acid sequences from the $\mathrm{N}$ gene. The alignment of the amino acid sequences from the $\mathrm{N}$ gene 


\begin{tabular}{|c|c|c|c|c|c|c|c|c|}
\hline & $55^{*}$ & 56 & 57 & 58 & 59 & 60 & 61 & 62 \\
\hline JUN & $\mathbf{R}$ & $\mathrm{K}$ & $T$ & $\mathbf{K}$ & $\mathbf{R}$ & G & $E$ & $\mathbf{E}$ \\
\hline MAC & $\mathrm{R}$ & $\mathrm{K}$ & $\mathrm{N}$ & $\mathbf{K}$ & $\mathbf{R}$ & $\mathbf{G}$ & $\mathbf{E}$ & $\mathbf{E}$ \\
\hline GUA & $\mathbf{R}$ & $\mathbf{K}$ & $\mathbf{s}$ & $\mathbf{K}$ & $\mathbf{R}$ & $\mathbf{G}$ & D & D \\
\hline TAC & $R$ & $\mathrm{~K}$ & $\mathrm{~T}$ & $\mathbf{K}$ & $\mathbf{R}$ & $T$ & D & D \\
\hline PIC & $\mathbf{R}$ & $\mathbf{K}$ & D & $\overline{\mathbf{K}}$ & $\mathbf{R}$ & $T$ & $\vec{D}$ & $\mathrm{~s}$ \\
\hline LCM & $\mathbf{R}$ & $\mathbf{K}$ & $\mathbf{E}$ & $\mathbf{K}$ & $\mathbf{R}$ & D & D & $\mathbf{K}$ \\
\hline LAS JOS & $\mathbf{R}$ & $\mathbf{K}$ & $\mathbf{E}$ & $\overline{\mathbf{R}}$ & $\mathbf{R}$ & D & D & $\overline{\mathrm{N}}$ \\
\hline LAS GA391 & $\mathbf{R}$ & $\pi$ & 3 & $\mathbf{K}$ & $\mathbf{R}$ & D & $\mathbf{D}$ & G \\
\hline MOP & $\mathbf{R}$ & $\mathbf{K}$ & $\mathbf{E}$ & $\mathbf{K}$ & $\mathbf{R}$ & D & D & $\mathrm{s}$ \\
\hline
\end{tabular}

FIGURE 3. Probable antigenic site on the arenavirus nucleocapsid protein. Homology around a conserved pair of amino acids residues (K-R, Lys-Arg) shown in a hydrophilicity plot of Guanarito virus (PCGene; Intelligenetics, Mountain View, CA). The bold characters are the nucleotides included by the ANTIGEN program as part of the hydrophilic site. $*=$ residue number. New World arenaviruses: JUN $=$ Junin $;$ MAC $=$ Machupo; TAC $=$ Tacaribe PIC $=$ Pichinde Old World arenaviruses: $\mathrm{LCM}=$ lymphocytic choriomeningitis; LAS JOS = Lassa; LAS GA391 = Lassa; MOP = Mopeia. T = thr; $\mathrm{G}=$ gly; $\mathrm{E}=$ glu; $\mathrm{D}=$ asp; $\mathrm{N}=$ asn; $\mathrm{S}=$ ser; $\mathrm{L}=$ leu; $\mathrm{Q}=$ gln.

of the five arenaviruses (Figure 2) reveals the following actual percentages of divergence when GUA virus is taken as a reference and pairwise comparisons are made: $26 \%$ with JUN, $22 \%$ with MAC, $26 \%$ with Tacaribe, $41 \%$ with PIC, and $46 \%$ with LCM virus. No statistical difference was found $(P>0.20)$ between our analysis (20\% divergence using 246 amino acids) and when the entire $N$ gene amino acid sequence of TAC virus is compared with JUN virus (24\% divergence using 584 amino acids). ${ }^{22}$ Areas of conserved amino acid residues were found in a random distribution, but two regions of marked similarity between all strains (New World and Old World) were found at residues 198-210 and 238-246, with the latter mentioned previously. ${ }^{28}$

\section{DISCUSSION}

Limited sequence analysis of a portion of the viral genome of many virus strains, including poliovirus type 1 , dengue virus types 1 and 2 , and Venezuelan equine encephalitis viruses, has been used previously to generate phylogenetic trees that are consistent with serologic and epidemiologic relationships. ${ }^{14,29,30}$ The phylogenetic trees we generated using only a portion of the $\mathrm{N}$ gene open reading frame of five arenaviruses gave an identical topology and similar relative branch lengths to the one generated using the total $\mathrm{N}$ gene." The topology of the tree is also consistent with previous serologic studies showing that JUN and MAC are the most closely related New World arenaviruses, while GUA and TAC are more closely related to these than to PIC. ${ }^{31}$ Junin, MAC, TAC, and GUA viruses form a monophyletic group that is strongly supported by bootstrap analysis. Although our phylogenetic analysis did not indicate the probable progenitor of the New World arenaviruses, it does give more insight into their evolutionary relationships, which are in accord with previous genetic and antigenic analyses. ${ }^{11,31-33}$

Conserved blocks of amino acids can be identified across all the strains compared here and probably indicate important functional domains within the $\mathrm{N}$ protein that have been conserved during evolution from a common ancestor. ${ }^{28}$ On the other hand, regions of higher divergence probably define unique characteristics of individual viruses. In our study, a strong hydrophilic sequence, which suggests a potential antigenic site, is shared by both Old and New World arenaviruses. Only three epitopes, conserved among members of both groups, have been identified by monoclonal antibodies directed to the $\mathrm{N}$ protein. ${ }^{34-36}$ A large majority of epitopes on the $N$ protein do not cross-react between the TAC group and the LCM-Lassa group. ${ }^{36,37}$ The well-defined epitope (amino acids 116-129) for inducing a cytotoxic $\mathrm{T}$ lymphocyte (CTL) response in LCM-infected mice ${ }^{38,39}$ is not conserved among the New World arenaviruses. However, using synthetic peptides, a small antigenic site overlapping the CTL site mentioned above (amino acids 123-127) has been shown to be conserved among the Lassa and TAC group members. ${ }^{40}$ Therefore, it is important to better define common antigenic sites among arenaviruses for a better understanding of their structure and possible vaccine targets.

Within the potential antigenic site identified here, a cell attachment site (RGD) can be found (amino acids 59-61) in GUA virus. A conservative amino acid change (i.e., no charge difference) in the JUN and MAC sequence (Asp to Glu at amino acid 61) makes the potential cell attachment site conserved only among the three human pathogenic arenaviruses from the New World. The biologic significance of this site remains to be investigated.

Not all the arenaviruses with known human pathogenic potential have been studied to date (FLEX and SAB), so we do not yet know if they will segregate by either antigenic or genetic analyses. However, most of the arenaviruses and all of the human pathogenic ones are restricted to specific rodent host-reservoirs that they chronically infect as a strategy for survival. ${ }^{41}$ All but LCM virus have a limited geographic extension and strong host associations; GUA virus' association with the rodent Siamodon alstoni appears to have existed for a long time in localized areas, without spreading. ${ }^{3}$ Our data also support the hypothesis that GUA virus has been evolving independently in its endemic focus for some time. As previously proposed, it is reasonable to assume that each arenavirus has evolved independently and this accounts for their high rates of divergence, i.e., there is no genetic exchange among these viruses. 41,42

Since the rate of fixation of mutations (tempo) is presently unknown for GUA virus, we therefore cannot estimate how long ago it branched out from the rest of the arenavirus group. We do not yet understand the molecular mechanism (mode) by which these viruses mutate. Lassa is the only arenavirus for which some evidence exists to support the hypothesis that divergence among arenaviruses occurs by point mutation; the highest rate of mutation occurs in the third position of the codon (Lassa $\mathrm{N}$ gene open reading frame: first position $10.3 \%$, second position $6.1 \%$, third position 50.2\%). ${ }^{43}$ Present studies are directed at understanding the tempo and mode of GUA virus evolution.

Acknowledgments: We acknowledge the contributions of Drs. Rosalba Salas, Robert B. Tesh, and Scott C. Weaver, and the technical assistance of Meena Thayu.

Financial support: This work was supported in part by grants AI10984 and AI-01 124 from the National Institutes of Health and by grant DAMD17-94-J4004 from the Department of Defense.

Disclaimer: All procedures involving live viral particles were conducted under the safety guidelines published by CDC/NIH for han- 
dling human pathogens (Biosafety in Microbiological and Biochemical Laboratories, CDC/NIH, HHS pub. No. 88-8395, 1994).

Authors' addresses: Jean-Paul Gonzalez and Rebeca Rico-Hesse, Yale Arbovirus Research Unit, Department of Epidemiology and Public Health, Yale University School of Medicine, PO Box 208023, New Haven, CT 06520-8023. Anthony Sanchez, Special Pathogens Branch, Division of Viral and Rickettsial Diseases, National Center for Infectious Diseases, Centers for Disease Control and Prevention, 1600 Clifton Road, Atlanta, GA 30333.

\section{REFERENCES}

1. Salas R, Manzione NMC de, Tesh RB, Rico-Hesse R, Shope RB, Betancourt A, Godoy O, Bruzual R, Pacheco ME, Ramos B, Tamayo JG, Jaimes E, Vasquez C, Araoz F, Querales J, 1991. Venezuelan haemorrhagic fever. Lancet 338: 10331036.

2. Coimbra TLM, Nassar ES, Burattini MN, de Souza LTM, Ferreira IB, Rocco IM, Travassos da Rosa A, Vasconcelos PFC, Pinheiro FP Leduc JW, Rico-Hesse R, Gonzalez JP, Jarhling PB, Tesh RB, 1994. New arenavirus isolated in Brazil. Lancet 343: 391-392.

3. Tesh RB, Wilson ML, Salas R, Manzione NMC de, Tovar D, Ksjazek TG, Peters CJ, 1993. Field studies on the epidemiology of Venezuelan hemorragic fever: implication of the cotton rat Siamodon alstoni as the probable rodent reservoir. Am $J$ Trop Med Hyg 49: 227-235.

4. Carter MF, Biswal N, Rawis WE, 1973. Characterization of the nucleic acid of Pichinde virus. J Virol 11: 61-68.

5. Southern PJ, Bishop DHL, 1987. Sequence comparison among arenaviruses. Curr Top Microbiol Immunol 133: 19-39.

6. Iapalucci $S$, Lopez R, Rey O, Lopez N, Franze-Fernandez MT, Cohen G, Lucero M, Ochoa A, Zakin MM, 1989. Tacaribe virus $\mathrm{L}$ gene encodes a protein of 2210 amino acid residues. Virology 170: 40-47.

7. Salvato MS, 1993. Molecular biology of the prototype lymphocytic choriomeningitis virus. Salvato MS, ed. The Arenaviridae. Heinz Fraenkel-Conrat and Robert Wagner Series. New York and London: Plenum Press, 133-152.

8. Auperin DD, Galinski M, Bishop DHL, 1984. The sequence of the $\mathrm{N}$ protein gene and intergenic region of the S RNA of Pichinde arenavirus. Virology 134: 218-219.

9. Wulff H, Lange JV, Webb PA, 1978. Interrelationship among arenaviruses measured by indirect immunofluorescence. Intervirology 9: 344-350.

10. Oldstone MBA, 1975. Virus neutralization and virus-induced immune complex disease: virus-antibody union resulting in immunoprotection or immunologic injury -two different sides of the same coin. Prog Med Virol 19: 84-119.

11. Clegg JCS, 1993. Molecular phylogeny of the arenaviruses and guide to published sequence data. Salvato MS, ed. The Arenaviridae. Heinz Fraenkel-Conrat and Robert Wagner Series. New York and London: Plenum Press, 175-187.

12. Gonzalez JP, McCormick JB, Georges AJ, Kiley MP, 1984. Mobala virus: biological and physochemical properties of a new arenavirus isolated in the Central African Republic. Ann Virologie (Inst Pasteur) 135E: 145-158.

13. Obijesky JF, Marchenko AT, Bishp DHL, Cann BW, Murphy FA, 1974. Comparative electrophoretic analysis of the virus proteins of four thabdoviruses. J Gen Virol 22: 21-33.

14. Rico-Hesse R, Pallansh MA, Nottay BK, Kew OM, 1987. Geographic distribution of wild poliovirus type 1 genotypes. $\mathrm{Vi}$ rology 160: 311-322.

15. Sanger F, Nicklen S, Coulson AR, 1977. DNA sequencing with chain-terminating inhibitors. Proc Natl Acad SCi USA 74: 5363-5467.

16. Auperin DD, Compams RW, Bishop DHL, 1982. Nucleotide sequence conservation at the $3^{\prime}$ terminus of the virion RNA species of the New World and Old World arenaviruses. $\mathrm{Vi}$ rology 121: 200-203.

17. Ghiringhelli PD, Rivera-Pomar RV, Lozano M, Grau O, Romanowsky V, 1991. Molecular organization of Junin virus $S$ RNA: complete nucleotide sequence, relationship with other members of the Arenaviridae and unusual secondary structures. J Gen Virol 72: 2129-2141.

18. Higgins DG, Sharp PM, 1988. Clustal: a package for performing multiple sequence alignment on a microcomputer. Gene 73: $237-244$.

19. Swofford DL, 1991. PAUP: Phylogenetic Analysis Using Parsimony, Version 3.1. Champaign, IL: Illinois Natural History Survey.

20. Felsenstein J, 1985. Confidence limits on phylogenies: an approach using the bootstrap. Evolution 39: 783-791

21. Hopp TP, Woods KR, 1981. Prediction of protein antigenic determinants from amino acid sequences. Proc Natl Acad SCi USA 78: 3824-3828.

22. Romanowsky V, 1993. Genetic organization of Junin virus, the etiological agent of Argentine hemorrhagic fever. Salvato MS ed. The Arenaviridae. Heinz Fraenkel-Conrat and Robert Wagner Series. New York and London: Plenum Press, 51-83.

23. Griffiths CM, Wilson SM, Clegg JCS, 1992. Sequence of nucleocapsid protein gene of Machupo virus: close relationship with another South American pathogenic arenavirus, Junin. Arch Virol 124: 371-377.

24. Franze-Fernandez MT, Zetina C, Iapalucci S, Lucero MA Bouissou C, Lopez R, Rey O, Daheli M, Cohen GN, Zakin MM, 1987. Molecular structure and early events in the replication of Tacaribe arenavirus S RNA. Virus Res 7: 309324.

25. Romanowsky V, Matsura Y, Bishop DHL, 1985. Complete sequence of the S RNA of lymphocytic choriomeningitis virus (WE strain) compared to that of Pichinde arenavirus. Virus Res 3: 101-114.

26. Wilson SM, Clegg JCS, 1991. Sequence analysis of the S RNA of the African Arenavirus Mopeia: a unusual secondary structure feature in the intergenic region. Virology 180: 543-552.

27. Ruoslathi E, Pierschbacher MD, 1986. Arg-Gly-Asp, a versatile recognition signal. Cell 44: 517-518.

28. Clegg JCS, Oram JD, 1985. Molecular cloning of Lassa virus RNA: nucleotide sequence and expression of the nucleocapsid protein gene. Virology 144: 363-372.

29. Rico-Hesse R, 1990. Molecular evolution and distribution of dengue viruses type 1 and 2 in nature. Virology 174: 479 493.

30. Weaver SC, Bellew LA, Rico-Hesse R, 1992. Phylogenetic analysis of alphaviruses in the Venezuelan equine encephalitis complex and identification of the source of epizootic virus. Virology 191: 282-290.

31. Tesh RB, Jarhling PB, Salas R, Shope RE, 1994. Description of Guanarito virus (Arenaviridae: Arenavirus), the etiologic agent of Venezuelan hemorrhagic fever. Am J Trop Med Hyg 50: 452-459.

32. Gonzalez JP, McCormick JB, 1987. Essai sur un modele de coevolution entre arenavirus et rongeurs. Mammalia 50: 425438.

33. Howard CR, 1986. Arenaviruses. Perspect Med Virol 2: 130138.

34. Buchmeier MJ, Lewicki HA, Tomori O, Oldstone MBA, 1981. Monoclonal antibodies to lymphocytic choriomeningitis and Pichinde viruses: generation, characterization, and cross-reactivity with other arenaviruses. Virology 113: 73-85.

35. Malakhova IV, Kunitskaia LI, Surikova LE, Skolina TV, Vladiko AS, 1991. Monoclonal antibodies to the Machupo virus: their isolation and preliminary characteristics (in Russian). Vopr Virusol 36: 508-511.

36. Ruo SL, Mitchell SW, Kiley MP, Roumillat LF Fisher-Hoch SP, McCormick JB, 1991. Antigenic relatedness between arenaviruses defined at the epitope level by monoclonal antibodies. $J$ Gen Virol 72: 549-555.

37. Sanchez A, Pifat DY, Kenyon RH, Peters CJ, McCormick JB, Kiley MP, 1989. Junin virus monoclonal antibodies: characterization and cross-reactivity with other arenaviruses. $J$ Gen Virol 70: 1125-1132.

38. Whitton JL, Tishon A, Lewicki H, Gebhard J, Cook T, Salvato M, Joly E, Oldstone MBA, 1989. Molecular analysis of a five amino-acid cytotoxic T-lymphocyte (CTL) epitope: an im- 
munodominant region which induces nonreciprocal CTL cross reactivity. I Virol 63: 4303-4310.

39. Castrucci MR, Hou S, Doherty PC, Kawaoka Y, 1994. Protection against lethal lymphocytic choriomeningitis virus (LCMV) infection by immunization of mice with an influenza virus containing an LCMV epitope recognized by cytotoxic T lymphocytes. I Virol 68: 3486-3490.

40. Vladyko AS, Bystrova SI, Malkhova IV Kunitskaia LI, Lemeshko NN, Kras'ko AG, Kozhich AT, Luskasevitch IS, 1993. The localisation and preliminary characteristics of antigenic sites in the nucleocapsid protein of the Lassa virus (in Russian). Vopr Virusol 38: 30-34.
41. Childs JE, Peters CJ, 1993. Ecology and epidemiology of arenaviruses and their hosts. Salvato MA, ed. The Arenaviridae. Heinz Fraenkel-Conrat and Robert Wagner Series. New York and London: Plenum Press, 331-384.

42. Gonzalez JP, Buchmeier MJ, McCormick JB, Mitchell SW, Elliott LH, Kiley M, 1984. Comparative analysis of Lassa and Lassa-like arenavirus isolates from Africa. Compans RW, Bishop DHL, eds. Molecular Biology of Negative Strcutd Viruses. New York: Elsevier/North Holland, 201-208.

43. Clegg JCS, Wilson SM, Oram JD, 1990. Nucleotide sequence of the S RNA of Lassa virus (Nigerian strain) and comparative analysis of the arenavirus gene products. Virus Res 18 : $151-164$. 